\title{
PERBANDINGAN TEPUNG KENTANG DAN TEPUNG TERIGU TERHADAP KARAKTERISTIK NUGGET
}

\section{The Comparison of Potato (Solanum tuberosum L.) and Wheat Flour (Triticum) to Nugget Characteristics}

\author{
Vieri Alghifari*, Dewi Nur Azizah \\ Program Studi Pendidikan Teknologi Agroindustri, Universitas Pendidikan Indonesia \\ *alghifari.vieri@upi.edu
}

\begin{abstract}
ABSTRAK
Nugget merupakan salah satu jenis makanan siap saji yang cukup populer di masyarakat. Nugget adalah suatu bentuk produk daging giling yang dibumbui, kemudian diselimuti oleh perekat tepung, pelumuran tepung roti (breading), lalu dibekukan untuk mempertahankan mutunya selama penyimpanan. Salah satu bahan yang digunakan dalam pembuatan Nugget adalah tepung. Tepung berfungsi sebagai bahan pengisi dan pengikat untuk memperbaiki stabilitas emulsi, menurunkan penyusutan akibat pemasakan, memberi warna yang terang, meningkatkan elastisitas, membentuk tekstur yang padat dan menarik. Tepung yang biasa digunakan pada produk Nugget adalah tepung terigu. Sejauh ini, tepung kentang jarang dimanfaatkan dalam produk inovasi pangan. Oleh karena itu, diperlukan subtitusi tepung kentang pada pembuatan Nugget. Tepung kentang memiliki karakteristik, yaitu mempunyai daya serap yang tinggi, bertekstur halus, berasa sedikit manis, dan beraroma harum khas tepung kentang. Berkaitan dengan hal tersebut telah dilakukan penelitian dengan tujuan untuk mengetahui karakteristik Nugget ayam yang dihasilkan dengan perbandingan tepung kentang dan tepung terigu yang paling disukai panelis. Penelitian ini menggunakan metode percobaan secara deskriptif dengan perlakuan perbandingan antara tepung kentang dan tepung terigu sebanyak 0\%:100\%, 25\%:75\%, 50:50\%, 75\%:25\%, dan 100\%:0\%. Hasil penelitian menunjukkan, karakteristik Nugget ayam yang dihasilkan memiliki warna kuning agak pucat, beraroma daging dan khas Nugget, bertekstur cukup empuk, serta berasa khas Nugget dengan sedikit rasa kentang. Nugget dengan perbandingan tepung kentang dan tepung terigu $25 \%: 75 \%$ adalah yang paling disukai oleh panelis.
\end{abstract}

Kata kunci: Nugget, tepung kentang, tepung terigu

\begin{abstract}
Nugget is one type of fast food that is popular in the community. Nugget is a form of meat product which is seasoned, covered with flour gluten, loosened breadcrumbs (breading), and then frozen to maintain its quality during storage. One of the ingredients used in making Nuggets is flour. Flour serves as a filler and binder to improve emulsion stability, reduce shrinkage due to cooking, give a light color, increase elasticity, form a dense and attractive texture. The flour commonly used in Nuggets is wheat flour. So far, potato starch is rarely used in food innovation products. Therefore, it is necessary to substitute potato starch in making Nuggets. Potato flour has the characteristics of high absorption, smooth texture, slightly sweet taste, and a distinctive aroma of potato starch. In this research has been carried out with the aim of knowing the characteristics of the chicken Nuggets produced and the Nuggets with the ratio of potato starch and wheat flour that panelists like the most. This study used a descriptive experimental method. The treatment, namely the ratio between potato flour and wheat flour as much as $0 \%$ : $100 \%, 25 \%: 75 \%, 50 \%: 50 \%, 75 \%: 25 \%$, and $100 \%: 0 \%$. The results showed that the characteristics of the chicken Nuggets produced had a slightly pale yellow color, meat aroma and typical Nuggets, soft texture, and a distinctive taste of Nuggets and a little taste of potato and Nuggets with a ratio of potato flour and wheat flour $25 \%$ : $75 \%$ was the most preferred panelist.
\end{abstract}

Keywords: Nuggets, Potato flour, Wheat flour

\section{PENDAHULUAN}

Nugget merupakan salah satu jenis makanan siap saji yang cukup populer di masyarakat. Biasanya nugget dibuat dari daging yang memiliki potongan relatif kecil dan tidak beraturan, kemudian diolah menjadi ukuran yang lebih besar. nugget, seperti juga sosis, burger, dan kornet, 
telah menjadi salah satu pilihan masyarakat sebagai produk pangan yang praktis. nugget terbuat dari daging cincang yang telah dibumbui. Menurut Tanoto (1994), nugget adalah suatu bentuk produk daging giling yang dibumbui, kemudian diselimuti oleh perekat tepung, pelumuran tepung roti (breading), dan digoreng setengah matang, lalu dibekukan untuk mempertahankan mutunya selama penyimpanan. Salah satu bahan yang digunakan dalam pembuatan nugget adalah tepung. Tepung berfungsi sebagai bahan pengisi dan pengikat untuk memperbaiki stabilitas emulsi, menurunkan penyusutan akibat pemasakan, memberi warna yang terang, meningkatkan elastisitas, membentuk tekstur yang padat dan menarik.

Penggunaan tepung kentang pada produk makanan juga sebagai upaya penganekaragaman pangan berbasis kentang yang selama ini masih digalakkan oleh pemerintah. Menurut Murtiningsih dan Suyanti (2011), kandungan kalium kentang cukup tinggi, tetapi kandungan natrium tergolong rendah. Natrium memicu hipertensi, sedangkan kalium menurunkan tekanan darah, sehingga rasio kalium dan natrium yang tinggi pada kentang sangat menguntungkan bagi kesehatan karena dapat mencegah hipertensi. Pada Komposisi Pangan Indonesia (2009), kandungan kalium pada kentang sebesar $396 \mathrm{mg}$ dan natrium $7 \mathrm{mg}$ per $100 \mathrm{~g}$ lebih tinggi jika dibandingkan dengan tepung terigu yang kandungan kaliumnya hanya $0 \mathrm{mg}$ dan kandungan natriumnya $2 \mathrm{mg}$.

Tepung kentang memiliki karakteristik, yaitu mempunyai daya serap yang tinggi, tekstur halus, rasa sedikit manis, dan aroma harum khas tepung kentang. Penggunaan tepung kentang menjadi produk cookies sebagai upaya penganekaragaman pangan berbasis kentang yang selama ini dianjurkan oleh pemerintah (Fajiarningsih, 2013).

Tepung terigu adalah salah satu bahan pangan yang banyak dibutuhkan oleh konsumen rumah tangga dan industri makanan di Indonesia. Tepung terigu dapat diolah menjadi banyak produk, antara lain dapat digunakan sebagai bahan dasar berbagai macam produk olahan seperti mie, roti, kue, donat, dan berbagai aneka produk makanan kecil. Industri makanan berbahan baku tepung terigu berkembang sangat pesat di Indonesia, hal ini menyebabkan meningkatnya permintaan produk tepung terigu dari tahun ke tahun. Oleh karena itu, tepung terigu menjadi komoditas yang sangat penting bagi masyarakat Indonesia. Karena kebutuhan yang sangat tinggi, Indonesia sampai harus mengimpor tepung dari berbagai belahan dunia. Kekurangan ini dikarenakan tanaman gandum sebagai bahan dasar tepung terigu merupakan tanaman sub-tropis, sehingga tanaman ini kurang optimal pertumbuhannya di Indonesia yang beriklim tropis sehingga mengakibatkan kekurangan pasokan terigu yang kemudian diatasi dengan impor dari negara lain.

Upaya dalam mengurangi konsumsi tepung terigu yang semakin meningkat di Indonesia, maka diperlukan bahan makanan sumber karbohidrat yang lain dalam pengolahan pangan. Salah satu yang dapat dilakukan yakni mensubstitusikan tepung terigu dengan tepung dari sumber bahan pangan lain dalam pembuatan produk makanan. Kelompok umbi-umbian lokal berpotensi besar sebagai alternatif yang dapat dikembangkan sebagai pengganti tepung terigu. Ini juga dapat mengurangi ketergantungan terhadap impor tepung terigu yang semakin meningkat. Kelompok umbi - umbian yang dapat berpotensi besar sebagai alternatif bahan pangan untuk dikembangkan sebagai pengganti tepung terigu tersebut salah satunya adalah kentang.

Selain itu, tepung terigu ini pada umumnya mengandung gluten. Gluten adalah protein yang secara alami terkandung di semua jenis serealia atau biji-bijian yang tidak dapat larut dalam air dan bersifat elastis (lentur) sehingga mampu membentuk kerangka yang kokoh dan makanan yang kenyal pada saat dimakan. Gluten ini mengandung komponen protein yang disebut peptida. Kebanyakan orang menghindari gluten karena alasan kesehatan, terutama para penderita celiac disease (alergi terhadap protein gluten yang menyebabkan gangguan kekebalan). Berdasarkan latar belakang tersebut penulis tertarik untuk menggunakan tepung kentang sebagai pengganti tepung terigu. Pengaruh penambahan konsentrasi tepung kentang akan mempengaruhi karakteristik fisik, kimia, dan sensoris nugget yang dihasilkan. Tujuan dari penelitian ini adalah untuk mengetahui perbandingan antara tepung kentang dengan tepung terigu agar menghasilkan karakteristik fisik, kimia, dan sensoris pada nugget yang dihasilkan. 


\section{METODE PENELITIAN}

Penelitian ini menggunakan metode percobaan secara deskriptif dengan perlakuan yaitu perbandingan antara tepung kentang dan tepung terigu sebanyak $0 \%: 100 \%, 25 \%: 75 \%, 50 \%$ : $50 \%, 75 \%: 25 \%$, dan $100 \%: 0 \%$. Alat yang digunakan pada penelitian ini, yaitu pisau, spatula plastik, talenan, baskom, loyang, panci, dandang, kompor, dan timbangan. Bahan yang digunakan antara lain tepung kentang, tepung terigu, daging ayam, telur, minyak, bawang putih bubuk, merica bubuk, kaldu ayam bubuk, gula, dan garam. Tahapan penelitian ini dapat digambarkan dalam diagram alir sebagai berikut:

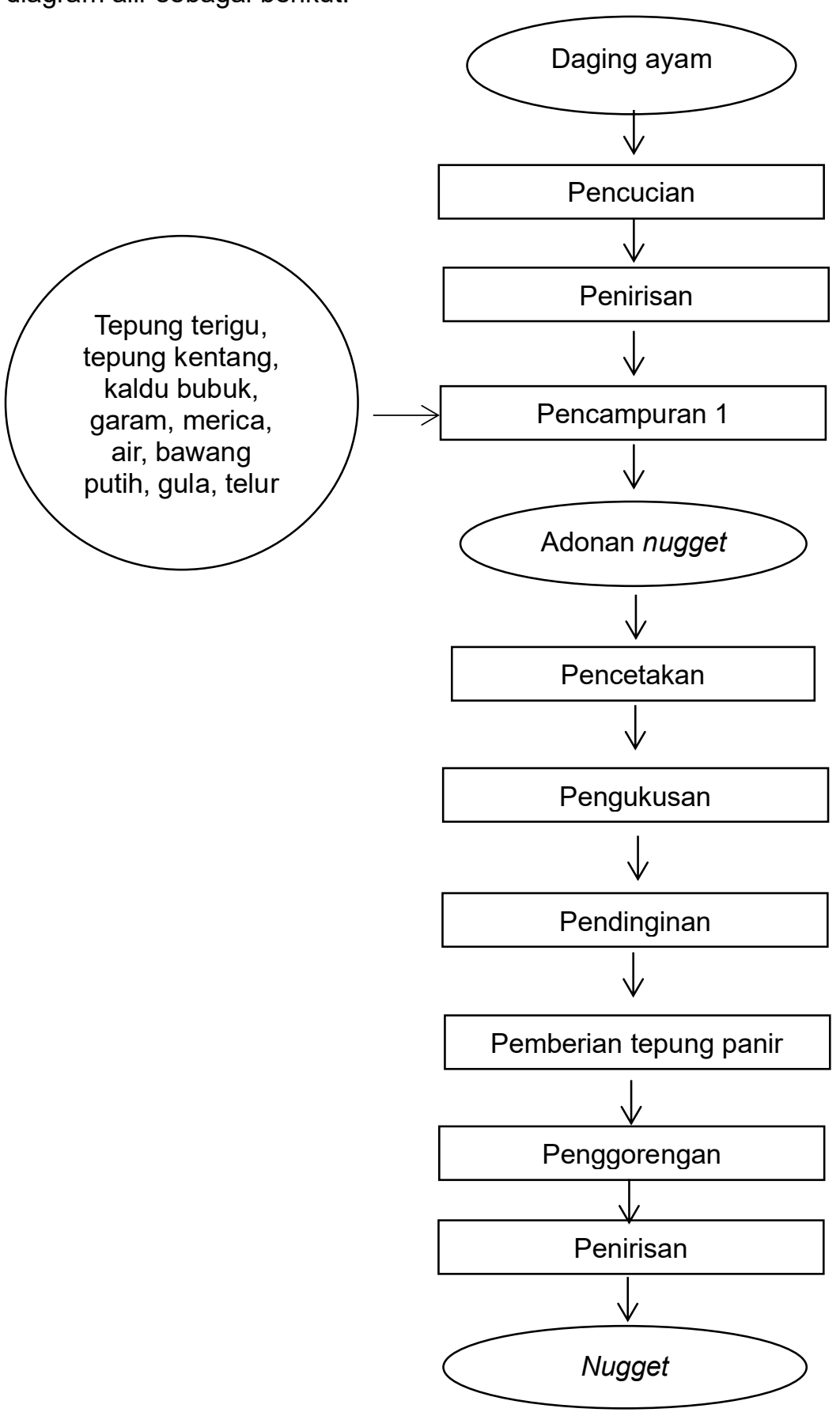

Gambar 1. Diagram Alir pembuatan Nugget Ayam 


\section{HASIL DAN PEMBAHASAN}

Bahan baku pada pembuatan nugget ini adalah daging ayam dan tepung kentang serta tepung terigu. Hasil pengamatan nugget yang dihasilkan terdapat pada Tabel 1.

Tabel 1. Karakteristik Produk Nugget

\begin{tabular}{ccc}
\hline $\begin{array}{c}\text { Perbandingan Tepung } \\
\text { Kentang dan Tepung Terigu }\end{array}$ & Karakteristik & Foto \\
\hline
\end{tabular}

$0 \%: 100 \%$

$25 \%: 75 \%$

$50 \%: 50 \%$
Warna yang dihasilkan yaitu kuning kecoklatan, beraroma sangat khas daging, tekstur yang cukup empuk, serta rasa yang sangat khas nugget ayam

Warna yang dihasilkan yaitu agak kuning, beraroma khas daging dan sedikit aroma kentang, tekstur yang cukup empuk, serta rasa yang sangat khas daging ayam dan sedikit rasa kentang

Warna yang dihasilkan yaitu kuning agak pucat, beraroma khas nugget dan sedikit aroma kentang, tekstur yang agak lembek dan sedikit rapuh, serta rasa yang sedikit khas nugget dan ada rasa kentang
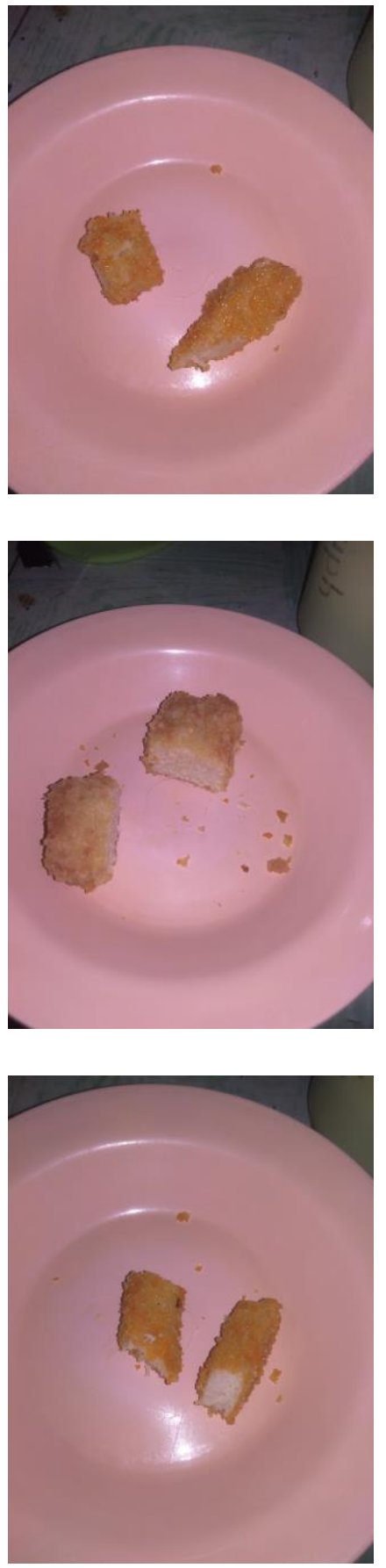


\begin{tabular}{|c|c|c|}
\hline $\begin{array}{c}\text { Perbandingan Tepung } \\
\text { Kentang dan Tepung Terigu }\end{array}$ & Karakteristik & Foto \\
\hline $75 \%: 25 \%$ & $\begin{array}{l}\text { Warna yang dihasilkan } \\
\text { yaitu kuning pucat, } \\
\text { beraroma khas nugget dan } \\
\text { cukup aroma kentang, } \\
\text { tekstur yang agak mudah } \\
\text { hancur, serta rasa yang } \\
\text { khas nugget dan agak } \\
\text { khas kentang }\end{array}$ & \\
\hline $100 \%: 0 \%$ & $\begin{array}{l}\text { Warna yang dihasilkan } \\
\text { yaitu agak pucat, } \\
\text { beraroma khas nugget dan } \\
\text { agak khas kentang, tekstur } \\
\text { yang sedikit mudah } \\
\text { hancur, serta rasa yang } \\
\text { khas nugget dan agak } \\
\text { khas kentang }\end{array}$ & \\
\hline
\end{tabular}

\section{Warna}

Berdasarkan Tabel 1 menunjukkan bahwa pada setiap perlakuan, nugget yang dihasilkan memiliki warna kuning pada bagian luarnya dan agak pucat pada bagian dalamnya. Warna kuning didapatkan dari hasil pelumuran dengan tepung panir dan juga lama waktu penggorengan yang dilakukan. Pada perbandingan tepung kentang dan tepung terigu $25 \%: 75 \%$ menghasilkan warna yang tidak pucat dibandingkan dengan perlakuan lainnya. Hal ini disebabkan karena semakin tinggi perbandingan tepung kentang yang digunakan, maka intensitas warna nugget yang dihasilkan semakin berkurang atau semakin pucat.

Menurut BSN (2014) pada SNI no. 6683 tentang Standar nugget Ayam, parameter warna tidak dijelaskan secara terperinci. Warna mempengaruhi penerimaan suatu bahan pangan karena umumnya penerimaan bahan yang pertama kali dilihat adalah warna. Warna yang menarik dapat meningkatkan penerimaan produk. Warna dapat mengalami perubahan saat pemasakan. Hal ini dapat disebabkan oleh hilangnya sebagian pigmen akibat pelepasan cairan sel pada saat pemasakan atau pengolahan, intensitas warna semakin menurun (Lestari, 2015).

\section{Aroma}

Berdasarkan Tabel 1 menunjukkan bahwa karakteristik aroma Nugget yang mendominasi adalah aroma khas daging ayam dan sedikit aroma kentang. Semakin tinggi perbandingan tepung kentang yang digunakan, semakin tinggi pula aroma kentang yang tercium pada Nugget tersebut.

Berdasarkan hasil pengamatan terhadap karakteristik produk, seluruh Nugget yang dihasilkan telah sesuai dengan SNI no. 6683 tentang Standar Nugget Ayam. Menurut BSN (2014) pada SNI no. 6683 tentang Standar Nugget Ayam, syarat mutu Nugget ayam adalah beraroma normal, tidak ada aroma yang mengganggu. Aroma khas yang dihasilkan tidak hanya berasal dari daging ayam saja, 
namun juga dipengaruhi oleh bahan-bahan tambahan lainnya, seperti tepung kentang dan berbagai macam bumbu. Menurut Nugraha (2019), perbedaan jenis tepung menyebabkan perbedaan aroma, karena aroma disebabkan oleh adanya komponen volatil yang terbentuk pada proses pemanasan dari bahan utama dan bumbu-bumbu. Dalam hal ini karena untuk keempat perlakuan menggunakan bahan utama, bumbu, dan proses pengolahan yang sama.

\section{Tekstur}

Berdasarkan Tabel 1 menunjukkan bahwa perbandingan tepung kentang yang semakin tinggi mengakibatkan tekstur Nugget yang semakin mudah hancur. Nugget dengan perbandingan tepung kentang dan tepung terigu 25\%:75\% menghasilkan tekstur yang cukup empuk atau normal, sesuai dengan Nugget pada umumnya. Berbanding terbalik Nugget dengan perbandingan tepung kentang dan tepung terigu 100\% : 0\% yang menghasilkan tekstur yang sedikit mudah hancur. Menurut Fajiarningsih (2013), karakteristik tepung kentang adalah warna putih kekuningan, tekstur halus, rasa sedikit manis, aroma harum khas kentang, dan kering. Umbi kentang yang digunakan dalam pembuatan tepung kentang adalah umbi kentang kuning dengan varietas granola. Karena tekstur yang halus tersebut, sehingga membuat penambahan tepung kentang dengan konsentrasi yang semakin tinggi menyebabkan karakteristik Nugget ini menjadi sedikit mudah hancur

Menurut Permadi (2012), proses penggilingan kemungkinan juga mempengaruhi tekstur Nugget, tekstur daging yang sudah digiling berbeda dengan tekstur daging utuh. Hal ini disebabkan karena pada saat proses penggilingan diduga terjadi pemutusan serabut-serabut otot oleh mesin penggiling, sehingga mempengaruhi tekstur daging giling. Owens (2001) menyatakan bahwa penggilingan atau pengecilan ukuran berfungsi agar area permukaan daging meluas, sehingga dapat terjadi ekstraksi protein. Ekstraksi protein sangat penting karena apabila tidak terjadi ekstraksi, maka daging tidak dapat menyatu saat dimasak dan hal ini dapat mempengaruhi tekstur Nugget yang dihasilkan.

Tepung kentang mempunyai kemampuan swelling power dan viskositas lebih tinggi dibandingkan dengan tepung lain seperti terigu, jagung, dan tapioka. Penambahan tepung sebagai pengikat didasarkan oleh kemampuan amilopektin yang dapat menambah elastisitas. Kandungan amilosa dan amilopektin pada tepung kentang sebesar $14,38 \%$ dan $76,9 \%$ (Arumsari, 2014). Menurut Winarno (2004), semakin kecil kandungan amilosa atau semakin tinggi kandungan amilopektin, maka semakin lekat bahan tersebut. Tepung kentang mempunyai kadar amilopektin yang tergolong tinggi.

\section{Rasa}

Berdasarkan Tabel 1 menunjukkan bahwa pada setiap perlakuan menghasilkan Nugget dengan intensitas rasa yang berbeda-beda. Nugget dengan perbandingan tepung kentang dan tepung terigu $25 \%: 75 \%, 50 \%: 50 \%, 75 \%: 25 \%$, dan $100 \%: 0 \%$ secara berturut-turut menghasilkan sedikit rasa kentang, ada rasa kentang, cukup terasa khas kentang, dan sangat terasa rasa khas kentang. Seiring dengan perbandingan tepung kentang yang semakin tinggi mengakibatkan rasa Nugget yang dihasilkan sedikit berkurang dan muncul rasa tepung kentang.

Berdasarkan hasil pengamatan terhadap karakteristik produk, seluruh Nugget yang dihasilkan telah sesuai dengan SNI no. 6683 tentang Standar nugget Ayam. Menurut BSN (2014) pada SNI no. 6683 tentang Standar Nugget Ayam, syarat mutu Nugget ayam adalah memiliki rasa yang normal, yaitu tidak terasa asing. Secara keseluruhan Nugget ini didominasi oleh rasa khas dan gurih yang berasal dari daging ayam dan bahan-bahan tambahan lainnya, seperti tepung kentang, bumbubumbu, dan bahan penyedap. Bahan penyedap seperti bawang putih, lada, pala, gula, dan garam memberikan cita rasa enak yang diinginkan dalam produk. Bahan penyedap yang ditambahkan dapat memberikan rasa yang khas dikarenakan terdapat kandungan volatil di dalamnya.

\section{Pengujian Organoleptik}

Pengujian sifat organleptik menggunakan uji hedonik dilakukan untuk mengetahui tingkat kesukaan panelis terhadap Nugget yang dihasilkan. Parameter yang diuji dalam Nugget ini meliputi warna, aroma, tekstur, dan rasa. 


\section{Warna}

Nilai rata-rata hasil uji hedonik terhadap atribut warna Nugget ayam dapat dilihat pada Gambar 2.

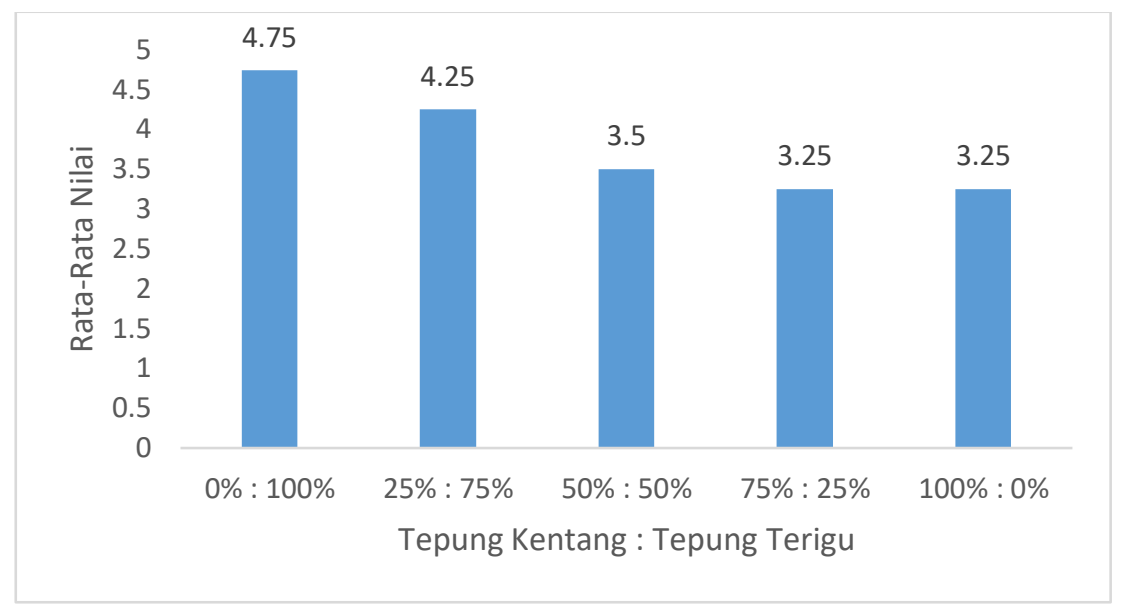

Gambar 2. Nilai Rata-rata Hasil Uji Hedonik terhadap Warna Nugget Ayam

Berdasarkan Gambar 2 menunjukkan bahwa nilai rata-rata hasil uji hedonik terhadap warna Nugget ayam diperoleh 3,25 - 4,75. Nilai rata-rata tertinggi sebesar 4,75 diperoleh dari perbandingan tepung kentang dan tepung terigu $0 \%: 100 \%$. Nilai rata-rata terendah sebesar 3,25 dengan karakteristik produk agak pucat diperoleh dari perbandingan tepung kentang dan tepung terigu $75 \%$ : 25\% dan 100\%: 0\%. Nilai rata-rata sebesar 4,25 dengan karakteristik produk agak kuning diperoleh dari perbandingan tepung kentang dan tepung terigu 25\%:75\%. Nilai rata-rata sebesar 3,50 diperoleh dari perbandingan tepung kentang dan tepung terigu 50\%:50\%.

Nugget yang paling disukai oleh panelis adalah pada perbandingan tepung kentang dan tepung terigu $25 \%$ : 75\% dikarenakan warnanya baik warna bagian luar maupun warna bagian dalam yang hampir mendekati warna Nugget di pasaran. Kesukaan panelis terhadap warna Nugget ini disebabkan karena penggunaan tepung panir di bagian luar dan juga tingkat kematangan yang sesuai.

\section{Aroma}

Nilai rata-rata hasil uji hedonik terhadap atribut warna Nugget ayam dapat dilihat pada Gambar 3.

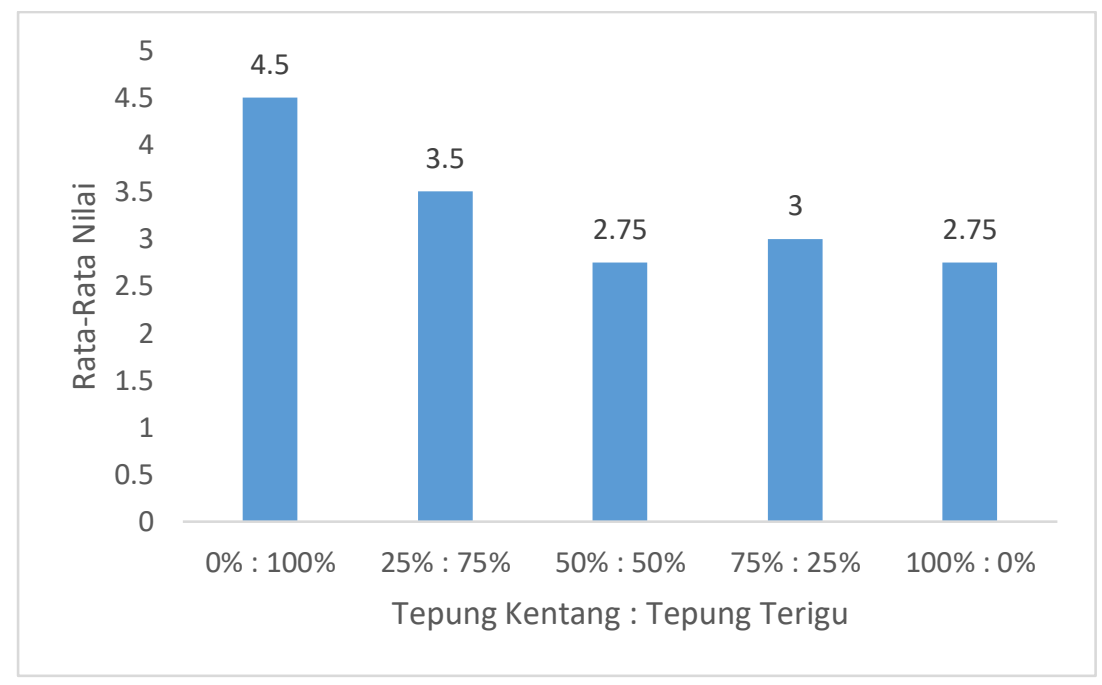

Gambar 3. Nilai Rata-rata Hasil Uji Hedonik terhadap Aroma Nugget Ayam 
Berdasarkan Gambar 3 menunjukkan bahwa nilai rata-rata hasil uji hedonik terhadap aroma Nugget ayam diperoleh $2,75-4,50$. Nilai rata-rata tertinggi sebesar 4,50 diperoleh dari perbandingan tepung kentang dan tepung terigu $0 \%: 100 \%$. Nilai rata-rata terendah sebesar 2,75 dengan karakteristik produk beraroma agak khas kentang diperoleh dari perbandingan tepung kentang dan tepung terigu 100\%:0\% dan 100\%:0\%. Nilai rata-rata sebesar 3,50 dengan karakteristik produk beraroma khas daging dan sedikit aroma kentang diperoleh dari perbandingan tepung kentang dan tepung terigu $25 \%: 75 \%$. Nilai rata-rata sebesar 3,00 diperoleh dari perbandingan tepung kentang dan tepung terigu $75 \%: 25 \%$.

Nugget yang paling disukai oleh panelis adalah pada perbandingan tepung kentang dan tepung terigu $25 \%: 75 \%$. Nugget ini memiliki aroma yang normal, yaitu aroma daging yang tidak terlalu menyengat dan juga tidak adanya aroma bahan lain yang mengganggu.

\section{Tekstur}

Nilai rata-rata hasil uji hedonik terhadap atribut aroma Nugget ayam dapat dilihat pada Gambar 4.

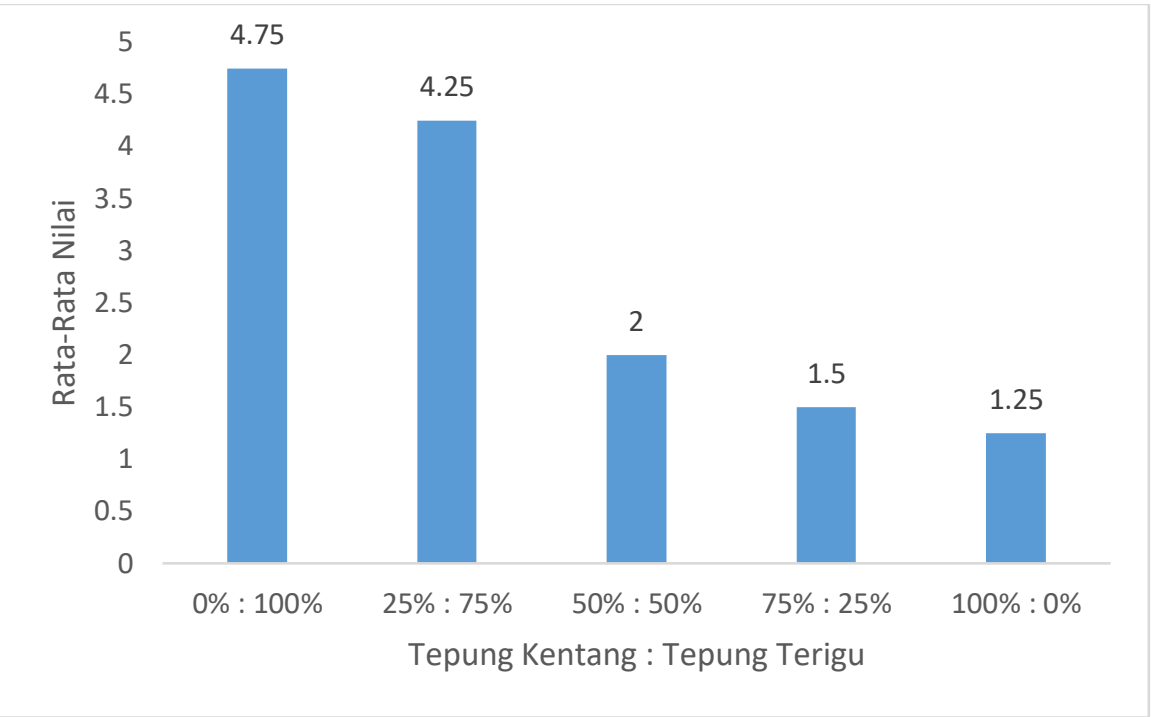

Gambar 4. Nilai Rata-rata Hasil Uji Hedonik terhadap Tekstur Nugget Ayam

Berdasarkan Gambar 4 menunjukkan bahwa nilai rata-rata hasil uji hedonik terhadap tekstur Nugget ayam diperoleh $1,25-4,75$. Nilai rata-rata tertinggi sebesar 4,75 diperoleh dari perbandingan tepung kentang dan tepung terigu $0 \%: 100 \%$. Nilai rata-rata terendah sebesar 1,25 dengan karakteristik produk sedikit mudah hancur diperoleh dari perbandingan tepung kentang dan tepung terigu 100\%: $0 \%$ dan 100\%: $0 \%$. Nilai rata-rata sebesar 4,25 dengan karakteristik produk cukup empuk diperoleh dari perbandingan tepung kentang dan tepung terigu 25\%:75\%. Nilai rata-rata sebesar 2,00 diperoleh dari perbandingan tepung kentang dan tepung terigu $50 \%: 50 \%$. Nilai ratarata sebesar 1,50 diperoleh dari perbandingan tepung kentang dan tepung terigu $75 \%: 25 \%$.

Nugget yang paling disukai oleh panelis adalah pada perbandingan tepung kentang dan tepung terigu $25 \%: 75 \%$. Nugget ini memiliki tekstur yang hampir mendekati tekstur Nugget yang ada di pasaran. 


\section{Rasa}

Nilai rata-rata hasil uji hedonik terhadap atribut rasa Nugget ayam dapat dilihat pada Gambar 5.

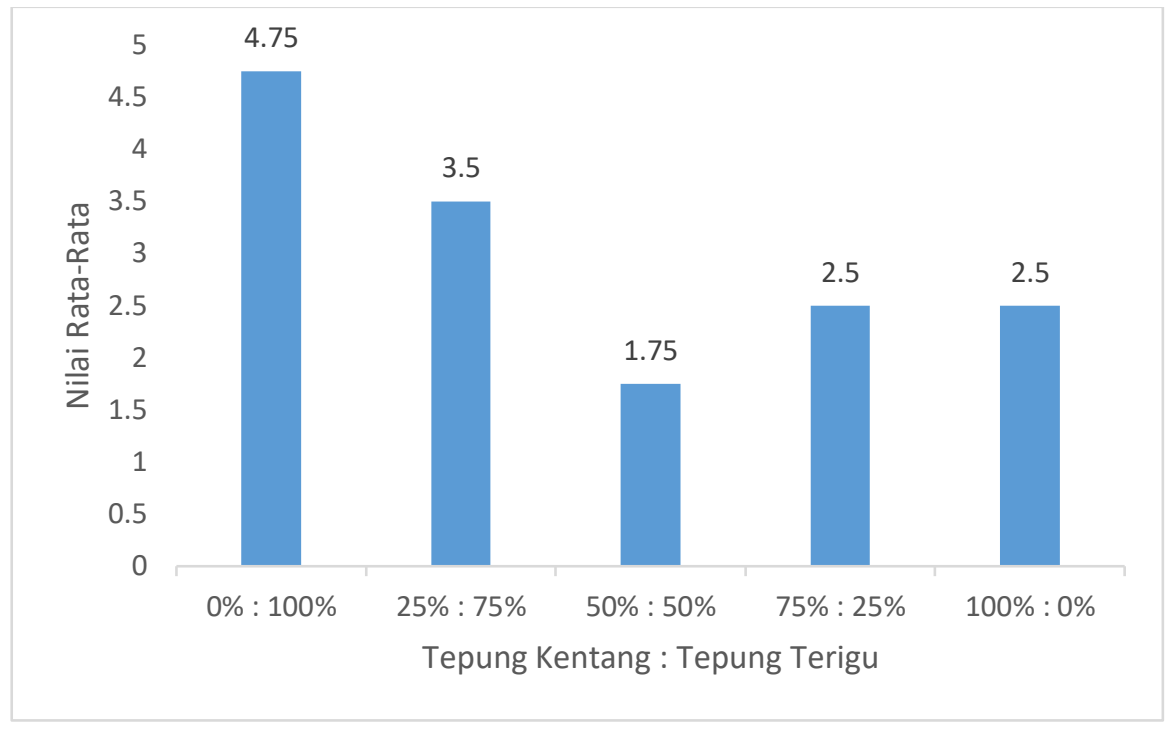

Gambar 5. Nilai Rata-rata Hasil Uji Hedonik terhadap Rasa Nugget Ayam

Berdasarkan Gambar 5 menunjukkan bahwa nilai rata-rata hasil uji hedonik terhadap rasa Nugget ayam diperoleh $1,75-4,75$. Nilai rata-rata tertinggi sebesar 4,75 diperoleh dari perbandingan tepung kentang dan tepung terigu $0 \%: 100 \%$. Nilai rata-rata terendah sebesar 1,75 dengan karakteristik produk sedikit khas Nugget diperoleh dari perbandingan tepung kentang dan tepung terigu $50 \%: 50 \%$ dan 100\%: $0 \%$. Nilai rata-rata sebesar 3,50 dengan karakteristik produk sedikit rasa kentang diperoleh dari perbandingan tepung kentang dan tepung terigu $25 \%: 75 \%$. Nilai ratarata sebesar 2,50 diperoleh dari perbandingan tepung kentang dan tepung terigu $75 \%: 25 \%$ dan $100 \%: 0 \%$.

Nugget yang paling disukai oleh panelis adalah pada perbandingan tepung kentang dan tepung terigu $25 \%: 75 \%$. Hal tersebut dikarenakan perbandingan antara tepung kentang dan tepung terigu yang bisa dikatakan pas dengan penambahan bahan-bahan yang lainnya. Sehingga Nugget dengan perbandingan tepung kentang dan tepung terigu $25 \%: 75 \%$ adalah yang paling disukai oleh panelis.

\section{KESIMPULAN}

1. Secara keseluruhan, karakteristik Nugget dengan perbandingan tepung kentang dan tepung terigu menghasilkan produk yang berwarna kuning agak pucat, beraroma daging dan khas Nugget, tekstur yang cukup empuk, serta berasa khas Nugget dan terdapat sedikit rasa kentang.

2. Nugget dengan perbandingan tepung kentang dan tepung terigu $25 \%: 75 \%$ adalah yang paling disukai oleh panelis.

\section{DAFTAR PUSTAKA}

Apriyani, D. F. (2013). Pengaruh Perbandingan Tepung Terigu Dan Tepung Pati Garut (Maranta Arundinacea L) Pada Daya Kembang Dan Daya Terima Donat (Doctoral dissertation, Universitas Muhammadiyah Surakarta).

Arumsari, M. D., Darmanto, Y. S., \& Riyadi, P. H. (2014). Pengaruh Perbedaan Konsentrasi Tepung Kentang (Solanum Tuberosum) terhadap Karakteristik Pasta dari Ikan Air Tawar, Payau dan Laut. Jurnal Pengolahan dan Bioteknologi Hasil Perikanan, 3 (3), 75-81.

Badan Standardisasi Nasional. (2014). Standar Nasional Indonesia (SNI) No. 6683:2014. Standar Nugget Ayam. Jakarta : Badan Standardisasi Nasional 
Fajiarningsih, H. (2013). Pengaruh Penggunaan Komposit Tepung Kentang (Solanum tuberosum L) terhadap Kualitas Cookies (Doctoral dissertation, Universitas Negeri Semarang).

Hidayati, A., \& Aisyiyah, S. (2012). Aplikasi Teknik Pembuatan Chicken Nugget Dalam Upaya Peningkatan Pendapatan Ibu-lbu Rumah Tangga Di Wilayah Kelurahan Dinoyo Malang. Jurnal Dedikasi, 5 (1). 1-9

Gumilar, J., O. Rachmawan, \& W. Nurdyanti. (2011). Kualitas Fisikokimia Naget Ayam yang Menggunakan Filer Tepung Suweg (Amorphophallus campanulatus). Jurnal IImu Ternak, 11 (1), $1-5$.

Lestari, N. (2015). Substitusi Tepung Tapioka Dengan Tepung Biji Nangka (Arthocarpus Heterophylluslamk.) Terhadap Kualitas Fisik Dan Organoleptik Nugget Daging Ayam (Doctoral dissertation, Universitas Islam Negeri Sultan Syarif Kasim Riau)

Nisa, T. K. (2013). Pengaruh Substitusi Nangka Muda (Artocarpus Heterophyllus Lmk) Terhadap Kualitas Organoleptik Nugget Ayam. Food Science and Culinary Education Journal, 2(1). 6370

Nugraha, Bagas Dwi, dkk. 2019. Sifat Fisiokimia dan Organoleptik Nugget Ayam dengan Penambahan Jenis Tepung yang Berbeda. Fakultas Teknologi Pertanian Universitas Semarang : Semarang

Permadi, S. N., Mulyani, S., \& Hintono, A. (2012). Kadar Serat, Sifat Organoleptik, dan Rendemen Nugget Ayam yang Disubstitusi dengan Jamur Tiram Putih (Plerotus ostreatus). Jurnal Aplikasi Teknologi Pangan, 1 (4), 115-118.

Widyastuti, E. S., Widati, A. S., Hanjariyanto, R. D., \& Avianto, M. Y. (2010). The Quality of Chicken Nuggets With Addition Gouda Cheese. Jurnal IImu dan Teknologi Hasil Ternak (JITEK), 5(1), 1-10.

Winarno, F. G. (2004). Kimia Pangan dan Gizi. PT Gramedia Pustaka Utama. Jakarta. 